\title{
Survey Aplikasi Pemodelan Dan Simulasi Proses Bisnis Open Source
}

\author{
Muhammad Ainul Yaqin ${ }^{1}$, Muhammad Julkarnain ${ }^{2}$, Kevin Syafri $^{3}$, Nurchaerani Kadir ${ }^{4}$
}

\begin{abstract}
Pemodelan dan simulasi proses bisnis adalah suatu proses yang melakukan perancangan suatu kondisi dengan menggunkan sistem pemodelan dan sistem simulasi dengan proses bisnis berbasis open source. Dalam perancangan sistem, sistem yang akan dibangun belum ada (baru ada secara "hipotetis"). Untuk membuat prediksi, harus dibuat model sistem tersebut. Seandainya pun ada sistem yang sebenarnya, sering sangat mahal (biaya dan waktu) atau sangat berisiko tinggi bahkan berbahaya untuk ber-eksperimen dengan sistem yang sesungguhnya. Untuk suatu studi dalam bidang tertentu, tidak perlu keseluruhan detail sistem dipelajari, perlu penyederhanaan dengan model. Perlu meng-identifikasi Entitas, Atribut, dan Aktivitas yang relevan dalam sistem Pemodelan. Gejala /proses yang akan ditirukan perlu dipahami, antara lain dengan jalan menentukan unsurunsur yang berperan. Unsur tersebut saling berinteraksi, saling berhubungan dan saling berketergantungan. Dari unsur dan keterkaitannya, dapat disusun gagasan atau konsep mengenai gejala/proses yang disimulasikan. Penyedia solusi open source terkemuka di dunia, hari ini meluncurkan paket aplikasi business process management berbasis open source yang paling komprehensif dalam industri IT.
\end{abstract}

Kata Kunci-Antrian, AnyLogic, Arena, ProModel.

\section{PENDAHULUAN}

$\mathrm{P}$ erkembangan teknologi informasi tidak hanya digunakan sebagai pendukung dalam aktivitas suatu perusahaan atau instansi pemerintahan melainkan telah digunakan sebagai alat pendukung dalam mengambil keputusan dan juga sebagai alat untuk menganalisis.

Manuscript received July 22, 2018. This work was supported in part by Informatics Engineering Department of Maulana Malik Ibrahim Islamic State University.

Muhammad Ainul Yaqin is with the Informatic Engineering Departement of Maulana Malik Ibrahim Islamic State University , Malang, Indonesia ( email yaqinov@ti.uin-malang..ac.id)

Muhammad Julkarnain is with the Informatic Engineering Departement of Maulana Malik Ibrahim Islamic State University, Malang, Indonesia.

Kevin Syafri is with the Informatic Engineering Departement of Maulana Malik Ibrahim Islamic State University, Malang, Indonesia.

Nurchaerani Kadir is with the Informatic Engineering Departement of Maulana Malik Ibrahim Islamic State University, Malang, Indonesia.
Simulasi memberikan kemampuan yang tak tertandingi untuk membayangkan dunia apa adanya dan seperti apa adanya dunia yang lebih baik dari produksi yang efisien, rantai pasokan yang responsif dan pengiriman kesehatan yang ideal. Berbagai alat dalam survei perangkat lunak ini menyediakan beragam rangkaian produk yang memungkinkan analis membangun, melihat, dan menganalisis model kompleks untuk berbagai aplikasi. Selain itu, sebagai puncak lebih dari setengah abad pembangunan, simulasi jauh lebih dari "alat terakhir" seperti yang pernah dijelaskan. Simulasi sekarang adalah teknologi dewasa yang memungkinkan studi yang bervariasi, rumit, dan mendetail tentang dunia sebagaimana mestinya.

Manfaat perangkat lunak simulasi dari pengembangan perangkat lunak dan perangkat keras yang konvergen. Pemodelan simulasi adalah sifatnya yang intensif secara komputasi. Suatu model analitik dapat direduksi menjadi rumus yang mudah, tetapi simulasi memperoleh fleksibilitasnya melalui konstruksi langsung dari realisasi sampel dari proses lengkap yang diteliti, paling sering direplikasi dan diulang untuk parameter atau konfigurasi lain.

Alat-alat ini dirancang untuk membantu pengguna dalam membangun model, yang merupakan deskripsi realitas sebagaimana adanya atau yang dibayangkan, tetapi model ini kemudian digunakan untuk menguraikan secara terperinci bagaimana realitas itu mungkin berperilaku, seperti halnya estimasi izin variabilitas. Selain itu, setiap alat berisi alat visual yang juga bergantung pada akses ke alat visualisasi canggih seperti rendering tiga dimensi dari hasil model.

Alat-alat dalam survei ini sebagian besar dikhususkan untuk simulasi kejadian diskrit, cocok untuk sejumlah besar masalah dunia nyata yang berkisar dari layanan, manufaktur, transportasi dan rantai pasokan, operasi militer atau logistik, komunikasi dan bahkan pemrosesan komputer. Beberapa alat dirancang untuk kelas umum masalah pemodelan, sementara yang lain fokus pada aplikasi di area fokus seperti manufaktur, industri layanan atau perawatan kesehatan, sementara ProModel memiliki spesialisasi MedModel dan Patient Flow Simulator, untuk contoh. Banyak dari 
simulator umum memiliki kemampuan untuk membangun templat atau pustaka khusus, sehingga organisasi dapat membangun model khusus mereka sendiri yang membangun pengalaman dan pengetahuan pemodelan terakumulasi.

Ketika alat-alat simulasi tumbuh telah matang, itu juga menjadi jelas bahwa simulasi menyediakan lebih dari kemampuan untuk mengisi celah dalam analisis matematis. Sebagai contoh, model analitik dapat dibatasi oleh asumsi terbatas atau menyediakan beberapa aspek dari sistem tetapi tidak yang lain. Sebagai contoh, banyak model antrian menyediakan sarana steady-state tetapi informasi yang kurang rinci tentang variabilitas proses. Lebih penting lagi, simulasi menyediakan kemampuan untuk secra visual mendemonstrasikan perilaku sistem yang sangat penting untuk komunikasi, analisis, pemasaran dan sering untuk verivikasi model dan validasi. Tentu saja visualisasi berbicara kepada khalayak yang lebih luas daripada kebanyakan ringkasan statistik, tidak peduli seberapa baik ditampilkan.

Peningkatan daya komputasi yang dikombinasikan dengan peningkatan dalam analisis dan simulasi proses acak "infrastruktur" juga berarti bahwa produk simulasi modern mampu memberikan jawaban yang lebih tepat. Hasil simulasi adalah perkiraan statistik, tetapi perbaikan dalam analisis yang dikombinasikan dengan kekuatan untuk memperoleh replikasi signifikan telah sangat meningkatkan ketepatan perkiraan statistik dan kekuatan perbandingan di antara skenario yang berbeda. Vendor telah mengeksploitasi penelitian dan pengembangan dalam perhitungan dan analisis untuk memperbaiki produk mereka.

Simulasi kemungkinan alat yang paling banyak digunakan untuk analisis sistem baru. Kombinasi fleksibilitas, akurasi, dan visualisasi adalah kombinasi kuat yang membuat analisis dapat diakses dan dipahami oleh khalayak luas. Ide simulasi adalah hal yang biasa: contoh mencakup olahraga dan permainan peran yang realistis, sementara banyak acara forensik termasuk penggambaran simulasi tentang bagaimana kejahatan dilakukan berdasarkan bukti yang tersedia. Demikian juga, meluasnya penggunaan animasi realistis dalam hiburan juga membuat penerimaan simulasi menjadi alami.

\section{TINJAUAN PUSTAKA}

\section{A. Pemodelan dan Simulasi}

Simulasi adalah program (software) komputer yang berfungsi untuk menirukan perilaku sistem nyata (realitas) tertentu. Tujuan simulasi adalah pelatihan (training), studi perilaku sistem (behaviour), hiburan atau permainan (game).
Proyek simulasi yang berhasil membutuhkan kombinasi kuantitatif dan kualitatif keterampilan, dukungan kuat dari berbagai bidang organisasi, dan seperangkat alat dan teknik untuk memungkinkan efektivitas dan inovasi. (Sadowski dan Grabu ,1999).

Pemodelan dan simulasi merupakan salah satu alat yang sering digunakan oleh manajemen dalam mempelajari atau menganalisis perilaku kerja dari suatu sistem atau proses.

\section{B. Model}

Model adalah suatu deskripsi atau analogi yang digunakan untuk membantu menggambarkan sesuatu yang tidak dapat diamati secara langsung (Webster's Collegiate Dic onary dalam Daellenbach \& McNickle, 2005). Pada umumnya model didefinisikan sebagai suatu representasi sistem nyata. Sistem nyata adalah sistem yang sedang berlangsung di dunia nyata dan menjadi permasalahan yang sedang diteliti.

Model dapat diklasifikasikan menjadi model ikonik, analog dan simbolik. Model ikonik adalah mempresentasikan suatu sistem atau benda menjadi suatu objek model yang wujudnya menyerupai sistem tersebut. Model analog adalah model yang mampu mempresentasikan sifat suatu sistem menjadi lebih sederhana. Model simbolik atau model matematis adalah representasi secara abstrak dari suatu sistem.

\section{C.Antrian}

Antrian adalah kedatangan pelanggan untuk mendapatkan pelayanan, menunggu untuk dilayani jika fasilitas pelayanan (server) masih sibuk, mendapatkan pelayanan dan kemudian meninggalkan sistem setelah dilayani. Dari sudut pandang pihak bank, efisiensi sistem dapat diestimasikan dengan mengevaluasi ukuran waktu rata-rata dari antrian tunggal (single queue) atau antrian terpisah. Suatu proses antrian adalah suatu proses hubungan dengan kedatangan seorang pelanggan pada suatu fasilitas pelayanan, kemudian menunggu dalam suatu baris (antrian) jika semua pelayan sibuk, dan akhirnya meninggalkan layanan tersebut. Sebuah sistem antrian adalah suatu himpunan pelanggan, pelayan dan suatu aturan yang mengatur kedatangan pada pelanggan dan pemrosesan masalah. (Sitompul, 2014)

Antrian merupakan kejadian yang sering kita alami atau kejadian yang kerap ada dalam kehidupan seharihari, misalnya saja menunggu antrian pada proses pembayaran di salah satu hypermarket, supermarket, pada pintu jalan tol, pada antrian bank dan masih banyak lagi contoh-contoh antrian yang biasa kita temukan. Antrian terjadi diakibatkan oleh kebutuhan akan layanan melebihi kapasitas yang ada pada fasilitas layanan yang terdapat dalam sistem, sehingga terjadi antrian oleh pengguna dan disebabkan oleh kesibukan dari layanan yang ada pada sistem. Pengertian antrian menurut Siagian, Antrian adalah suatu garis tunggu dari nasabah (satuan) yang memerlukan layanan dari satu atau lebih pelayanan/fasilitas layanan. (Fauziah, Agus na, \& Andryana, 2012) 
Ada 4 struktur dasar model antrian yang umum terjadi dalam sebuah antrian :

1. Single Channel Single Phase: menunjukkan hanya terdapat satu jalur masuk sistem pelayanan dan hanya terdapat satu fasilitas pelayanan

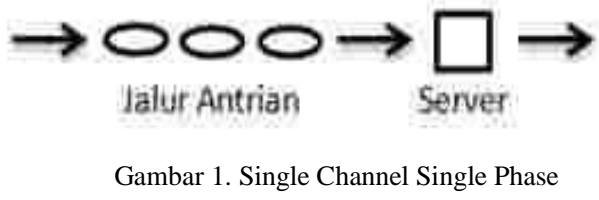

2. Single Channel Mul Phase: menunjukkan hanya terdapat satu jalur masuk sistem pelayanan dan terdapat dua atau lebih fasilitas pelayanan secara seri dalam jalur tersebut

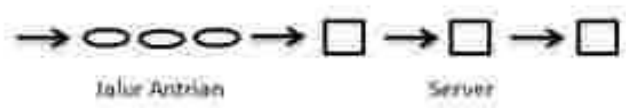

Gambar 2. Single Channel Mul Phase

3. Multi Channel Single Phase: menunjukkan terdapat dua atau lebih jalur masuk sistem pelayanan dan hanya terdapat satu fasilitas pelayanan dalam se ap jalurnya

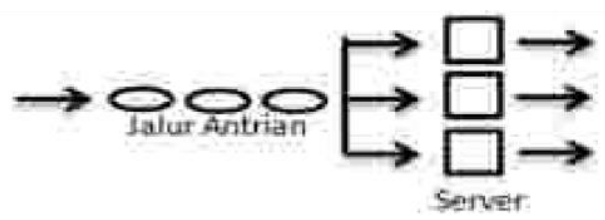

Gambar 3. Multi Channel Single Phase

4. Multi Channel Multi Phase: menujukkan terdapat dua atau lebih jalur masuk sistem pelayanan dan juga terdapat dua atau lebih fasilitas pelayanan secara seri dalam se ap jalurnya.

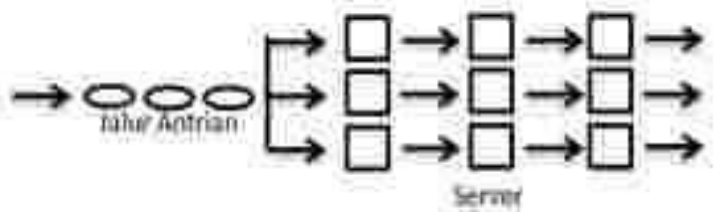

Gambar 4. Mul Channel Mul Phase

Tujuan dasar model-model antrian adalah untuk meminimumkan total dua biaya yaitu biaya langsung penyediaan fasilitas layanan dan biaya yang tidak langsung yang timbul karena para individu harus menunggu untuk dilayani.

\section{Software Pemodelan dan Simulasi Open Source}

- AnyLogic

Anylogic adalah pemodelan simulasi multimethod yang dikembangkan oleh The AnyLogic Company (former XJ Technologies). Ini mendukung acara berbasis agen, diskrit, dan metodologi simulasi dinamika sistem.

Anylogic adalah perangkat lunak simulasi sejauh lintas platform berfungsi pada Windows, macOS, dan Linux. AnyLogic digunakan untuk mensimulasikan: pasar dan kompetisi, perawatan kesehatan , manufaktur, rantai pasokan dan logistik, ritel, proses bisnis, sosial dan dinamika ekosistem, pertahanan, proyek dan manajemen aset, dinamika pejalan dan lalu lintas jalan, IT, aerospace.(Wikipedia).

\section{- Arena}

Arena adalah suatu perangkat lunak simulasi dan otomasi yang dikembangkan oleh System Modelling. Software Arena digunakan untuk membangun model eksperimen dengan menggunakan model-model yang menyatakan proses atau logika. Garis penghubung digunakan untuk menyatakan hubungan antar modul dan atau menyatakan aliran entitas. Software Arena dapat terintegrasi dengan baik dengan teknologi Microsoft termasuk Visual Basic. Software Arena juga mendukung diagram alir yang dibuat dengan Microsoft Visio, yang membaca Excel dan Acces. (Nursan , Lisa P, Qoyyimah, C.C, \& Hannas A, 2015).

\section{- ProModel}

ProModel merupakan sebuah software yang dapat membuat suatu simulasi kejadian diskrit yang memungkinkan pemodelan proses secara terus menerus. ProModel digunakan untuk mengevaluasi, merencanakan atau merancang manufaktur, pergudangan, logistik dan aplikasi operasional dan strategis lainnya.

Dalam ProModel 7.5 disediakan suatu fasilitas yang disebut dengan Stat::Fit. Stat::Fit adalah suatu aplikasi statistik yang digunakan untuk menentukan model statistik yang akan digunakan sebagai input simulasi menggunakan ProModel. Stat:fit memberikan kemudahan, kecepatan dan keakuratan dalam pengolahan data yang dimiliki. Stat::Fit digunakan untuk menguji distribusi suatu data dan pembangkitan bilangan random sesuai dengan distribusi yang diinginkan pemodel.

\section{METODOLOGI}

Pada penelitian ini, metode pengukuran yang akan dilakukan sebagai berikut:

Pertama, penelitian difokuskan pada pengamatan proses bisnis Banking Mandiri. Pengamatan ini bertujuan untuk mengetahui proses bisnis dari Banking Mandiri.

Kedua, penelitian dilanjutkan dengan melakukan perancangan Spesifikasi Kebutuhan Perangkat Lunak untuk menganalisis dan mendokumnetasikan kebutuhan pengguna terhadap sistem Pemodelan dan Simulasi Proses Bisnis. 
Ketiga, dilakukan pemodelan dan simulasi proses bisnis. Setelah itu mengidentifikasi permasalahan pada proses bisnis dan analisis perbaikan proses bisnis. Kemudian melakukan pemodelan dan simulasi proses bisnis. Selanjutnya melakukan perbandingan antara hasil.

\section{ANALISIS DAN PEMODELAN}

Pada penelitian ini, penulis menggunakan aplikasi AnyLogic, Arena, dan ProModel untuk melakukan Survey Aplikasi Pemodelan dan Simulasi Proses Bisnis Open Source dengan studi kasus proses bisnis Bangking. Alur dari proses bisnis Banking seperti pada gambar dibawah ini.

1. Menggunakan Anylogic

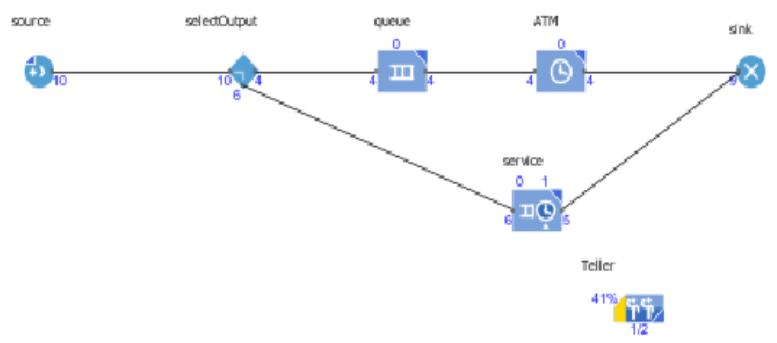

Gambar 4. Pemodelan dengan AnyLogic

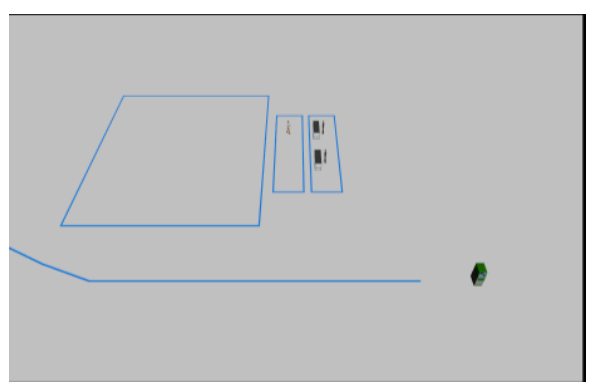

Gambar 5. Simulasi dengan AnyLogic

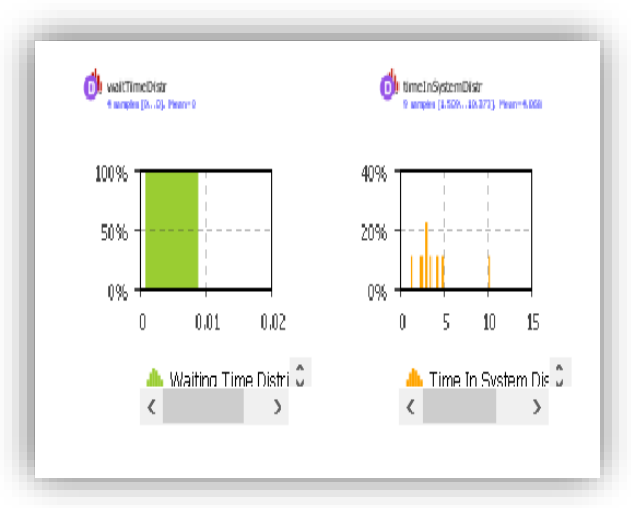

Gambar 6. Hasil Pemodelan \& Simulasi dengan AnyLogic

Pada percobaan di atas dapat di lihat bahwa AnyLogic dapat menampilkan hasil berupa Animasi 3D, dan Bagan berupa diagram baris dan diagram batang.

2. Menggunakan Arena

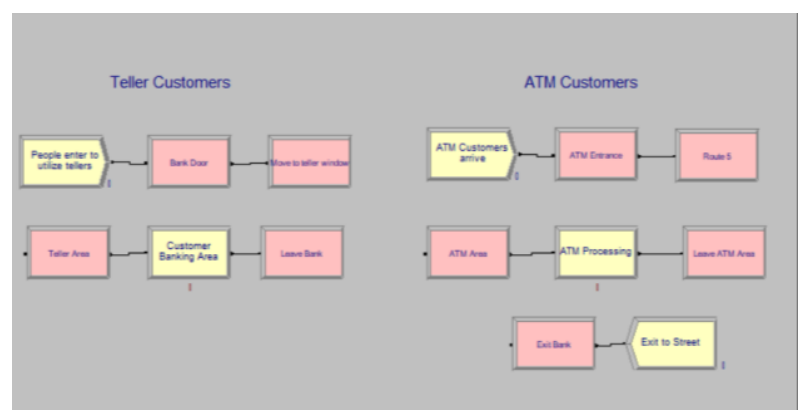

Gambar 7. Pemodelan dengan Arena

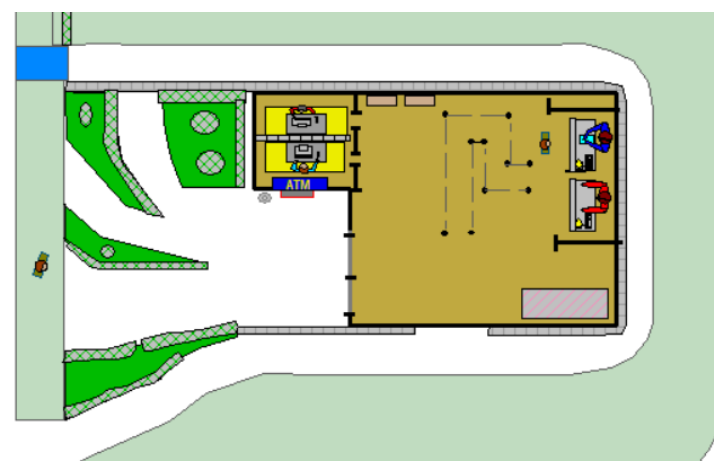

Gambar 8. Simulasi dengan Arena

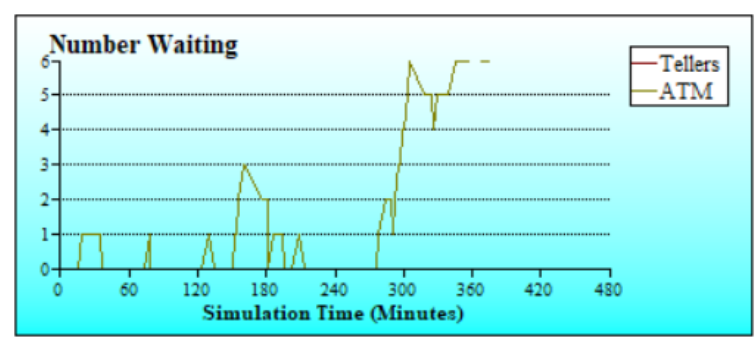

Gambar 9. Hasil Pemodelan dan Simulasi dengan Arena

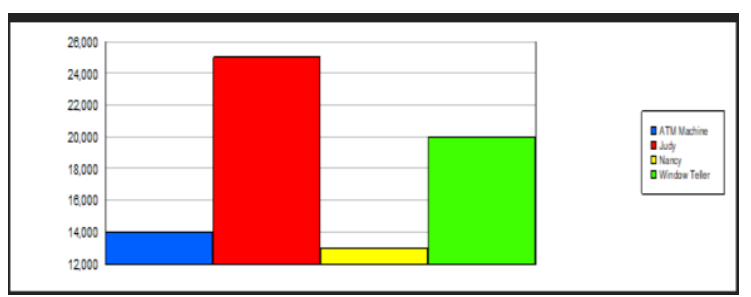

Gambar 10. Hasil Pemodelan dan Simulasi dengan Arena berupa Digram Batang

Pada percobaan di atas dapat dilihat bahwa dengan menggunakan Arena dapat dilakukan Pemodelan dan Simulasi sehingga menghasilkan output berupa diagram diagram batang, baris, dan file text yang dapat di generate ke Word, Excel dan html. Dengan menggunakan arena, dapat lihat juga dari tampak 3D. 
3. Menggunakan ProModel

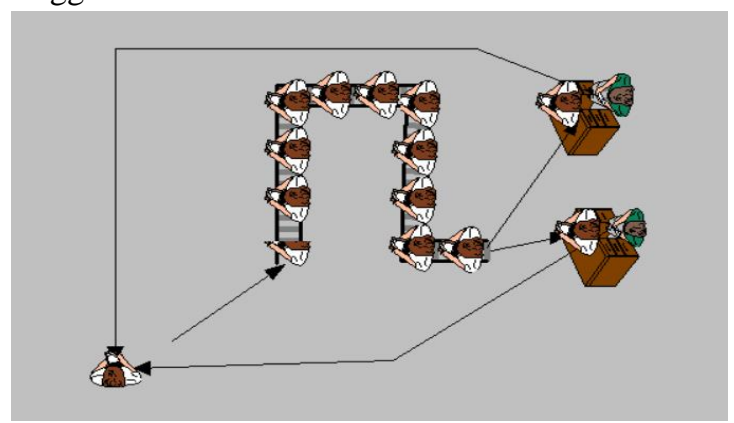

Gambar 11. Pemodelan dan Simulasi dengan Promodel

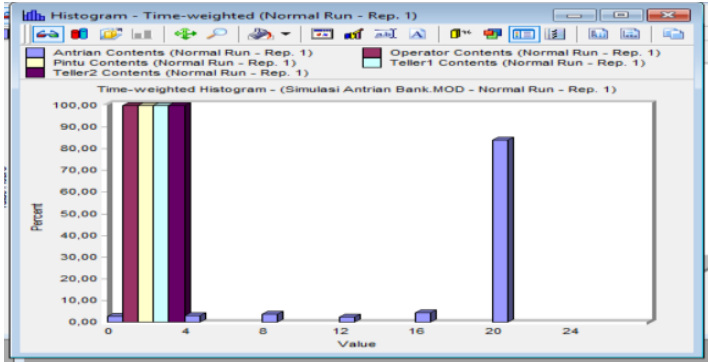

Gambar 12. Hasil Pemodelan dan Simulasi dengan Promodel

Pada percobaan diatas dapat lihat bahwa ProModel dapat menampilkan hasil berupa Laporan, diagram batang dan diagram baris.

\section{PEMBAHASAN}

Dalam penelitian ini, metode pengukuran diaplikasikan dalam tiga aplikasi yaitu AnyLogic, Arena, dan ProModel.

Dari hasil pemodelan dan simulasi di atas dapat di peroleh :

\section{- Kategori Feature}

Kategori Feature adalah Model permasalahan yang dapat diselesaikan oleh aplikasi tersebut

\begin{tabular}{|c|c|c|c|c|}
\hline No & Kriteria & AnyLogic & Arena & Promodel \\
\hline $\mathbf{1}$ & Mining & $\checkmark$ & - & - \\
\hline $\mathbf{2}$ & $\begin{array}{c}\text { Manufacturin } \\
\text { g }\end{array}$ & $\checkmark$ & $\checkmark$ & $\checkmark$ \\
\hline $\mathbf{3}$ & $\begin{array}{c}\text { Transportatio } \\
\text { n }\end{array}$ & $\checkmark$ & $\checkmark$ & - \\
\hline $\mathbf{4}$ & HealthCare & $\checkmark$ & $\checkmark$ & $\checkmark$ \\
\hline $\mathbf{5}$ & $\begin{array}{c}\text { Food \& } \\
\text { Baverage }\end{array}$ & - & $\checkmark$ & - \\
\hline $\mathbf{6}$ & Supply Chain & $\checkmark$ & $\checkmark$ & - \\
\hline
\end{tabular}

Tabel 1. Kategori Features

Jika dilihat dari tabel di atas dapat disimpulkan bahwa perbandingan dari 3 aplikasi tersebut yaitu aplikasi anylogic memiliki fitur terlengkap dari pada aplikasi lainnya. Adapun dilihat dari fitur yang menerapkan tentang 3 aplikasi tersebut aplikasi anylogic memiliki detail fitur yang lebih rinci dibandingkan dengan aplikasi arena dan aplikasi promodel.

\section{- Kategori Hasil}

Kategori hasil yang dimaksud adalah Hasil penelitian atau simulasi yang terdapat pada software tersebut.

Tabel 2. Kategori Hasil

\begin{tabular}{|c|c|c|c|c|}
\hline No & Kriteria & AnyLogic & Arena & Promodel \\
\hline 1 & $\begin{array}{c}\text { Generate } \\
\text { Word }\end{array}$ & $\checkmark$ & $\checkmark$ & - \\
\hline 2 & $\begin{array}{l}\text { Diagram } \\
\text { garis }\end{array}$ & $\checkmark$ & $\checkmark$ & $\checkmark$ \\
\hline 3 & $\begin{array}{l}\text { Diagram } \\
\text { Batang }\end{array}$ & $\checkmark$ & - & $\checkmark$ \\
\hline 4 & $\begin{array}{l}\text { Diagram } \\
\text { Lingkaran }\end{array}$ & $\checkmark$ & - & $\checkmark$ \\
\hline 5 & $\begin{array}{c}\text { Food \& } \\
\text { Baverage }\end{array}$ & - & $\checkmark$ & - \\
\hline 6 & $\begin{array}{l}\text { Supply } \\
\text { Chain }\end{array}$ & $\checkmark$ & $\checkmark$ & - \\
\hline
\end{tabular}

Jika dilihat dari tabel di atas dapat disimpulkan perbandingan antara 3 aplikasi tersebut dilihat dari Kriteria Hasil yaitu dari 3 aplikasi tersebut yakni aplikasi anylogic memiliki fitur terlengkap dari pada 2 aplikasi lainnya. Adapun dilihat dari fitur yang menerapkan tentang 3 aplikasi tersebut aplikasi anylogic memiliki detail fitur yang lebih rinci dibandingkan dengan aplikasi arena dan aplikasi promodel.

- Kategori Kompatibilitas Teknis

Kategori Teknis adalah kebutuhan slot dalam PC untuk Menjalankan Aplikasi tersebut.

Tabel 3. Kategori Kompatibilitas Teknis

\begin{tabular}{|c|c|c|c|c|}
\hline No & Kriteria & AnyLogic & Arena & ProModel \\
\hline 1 & $\begin{array}{l}\text { Supported } \\
\text { Operating } \\
\text { System }\end{array}$ & $\begin{array}{l}\text { Windows, } \\
\text { Mac, Linux }\end{array}$ & Windows & Windows \\
\hline 2 & $\begin{array}{l}\text { Perangkat } \\
\text { Lunak } \\
\text { Kompetibel } \\
\text { untuk } \\
\text { melakukan } \\
\text { fungsi } \\
\text { khusus }\end{array}$ & $\begin{array}{c}\text { Excel, Acces, } \\
\text { any database, } \\
\text { Stat::Fit, Any } \\
\text { Java//DLL }\end{array}$ & OptQuest & $\begin{array}{l}\text { Excel, } \\
\text { Access, } \\
\text { Stat:Fit, } \\
\text { MiniTab }\end{array}$ \\
\hline 3 & $\begin{array}{c}\text { Dikendalikan } \\
\text { atau } \\
\text { dijalankan } \\
\text { dengan } \\
\text { program } \\
\text { external }\end{array}$ & $\begin{array}{c}\text { Model } \\
\text { AnyLogic bisa } \\
\text { diekspor } \\
\text { sebagai } \\
\text { Aplikasi Java } \\
\text { yang bisa } \\
\text { dijalankan dari } \\
\text { / oleh yang } \\
\text { lain aplikasi. } \\
\text { Bisa juga } \\
\text { berjalan online } \\
\text { melalui } \\
\text { AnyLogic } \\
\text { Layanan web } \\
\text { cloud. }\end{array}$ & $\begin{array}{l}\text { Visual } \\
\text { Studio } \\
\text { untuk } \\
\text { tujuan }\end{array}$ & $\begin{array}{c}\text { Excel, } \\
\text { Access, C\#, } \\
\text { VB, VBA }\end{array}$ \\
\hline 4 & $\begin{array}{l}\text { Didukung } \\
\text { Multiprocess } \\
\text { or CPU }\end{array}$ & YES & YES & YES \\
\hline
\end{tabular}


Jika dilihat dari tabel di atas dengan Kategori Kompatibilitas Teknis dapat disimpulkan bahwa anyLogic dengan Kriteria Supported Operating System lebih unggul karena anyLogic dapat didukung sistem operasi yang berbasis Wimdows, Linux, dan Mac. Sedangkan Arena dan ProModel hanya di dukung sitem operasi Windows. Jika di lihat dari Kriteria Perangkat Lunak Kompetibel, anyLogic lebih unggul lagi karena merupakan Perangkat Lunak Kompetibel untuk melakukan fungsi khusus, seperti pada Excel, Acces, any database, Stat::Fit, any Java, dll. Sedangkan Arena hanya kompetibel pada OptQuest, dan Promodel hanya kompetibel pada Excel, Access, Stat::Fit, MiniTab.

- Kategori Animation

Tabel 4. Kategori Animation

\begin{tabular}{|c|c|c|c|c|}
\hline No & Kriteria & AnyLogic & Arena & ProModel \\
\hline $\mathbf{1}$ & Animasi & $\checkmark$ & - & - \\
\hline $\mathbf{2}$ & $\begin{array}{c}\text { Eksport } \\
\text { Animasi }\end{array}$ & $\checkmark$ & $\checkmark$ & - \\
\hline $\mathbf{3}$ & $\begin{array}{c}\text { Real- } \\
\text { Time } \\
\text { Viewing } \\
\text { 3D } \\
\mathbf{4}\end{array}$ & $\checkmark$ & $\checkmark$ & $\checkmark$ \\
\hline Animasi & $\checkmark$ & $\checkmark$ & $\checkmark$ \\
\hline
\end{tabular}

Pada tabel diatas dengan Kategori Animation menunjukkan bahwa dengan menggunakan AnyLogic dapat dilakukan Animasi, eksport Animasi, Real-Time Viewing, dan 3D animation. Sedangkan pada Arena hanya tidak bisa melakukan animasi dan pada ProModel hanya bisa melakukan Real-Time Viewing dan 3D animation.

- Kategori Model Aplikasi

Model Aplikasi Yang dimaksud adalah kategori model yang bisa dimodelkan oleh aplikasi tersebut.

Tabel 5. Kategori Model Aplikasi

\begin{tabular}{|c|c|c|c|c|}
$\mathbf{N o}$ & Kriteria & AnyLogic & Arena & Promodel \\
$\mathbf{1}$ & $\begin{array}{c}\text { Agent } \\
\text { Based }\end{array}$ & $\checkmark$ & - & - \\
$\mathbf{2}$ & $\begin{array}{c}\text { Descrete } \\
\text { Event }\end{array}$ & $\checkmark$ & - & - \\
\hline $\mathbf{3}$ & $\begin{array}{c}\text { Dynamic } \\
\text { System }\end{array}$ & $\checkmark$ & - & - \\
\hline
\end{tabular}

\section{KESIMPULAN}

Pada penelitian ini dilakukan analisis kualitas dari masing-masing Aplikasi Pemodelan dan Simulasi Proses Bisnis Open Source, yaitu Aplikasi AnyLogic, Aplikasi Arena, dan Aplikasi ProModel. Dari analisis yang dilakukan dengan cara mengukur kualitas masingmasing aplikasi di lihat dari 4 kriteria yaitu Katogori Marketing, Kategori hasil, Kategori kompatibilitas Teknis dan Kategori Animation, menunjukkan bahwa Software Aplikasi AnyLogic memiliki nilai kualitas yang tertinggi di bandingkan dengan aplikasi Aplikasi Arena dan Aplikasi ProModel.

\section{REFERENSI}

[1] Manuel Laguna, dan John Marklund, "Business Process Modeling Simulation and Design second edition", New York, 2013.

[2] Olfa Chebbi, dan Jouhaina Chaouachi, "Modeling On-demand Transit Transportation System Using an Agent-Based Approach.”, Tunisie, 2015.

https://link.springer.com/chapter/10.1007/978-3-319-24369-6 26

[3] Raja Ayu M., Leni M. dan Rini Sovia, "Pemodelan dan Simulasi Sistem Antrian Pelayanan Pelanggan Menggunakan Metode Monte Carlo Pada PT POS Indonesia(PERSERO) Padang", Padang, 2017. TI UPI Padang. IK, Vol. 6, No. 1.

[4] Yashinta, M., dan Estik, H., "Sistem antrian teller bank mandiri sebagai upaya meningkatkan efisiensi kecepatan transaksi, Padang: Fakultas Ekonomi Universitas 17 Agustus 1945 Surabaya. 2016. Volume 1, Nomor 1. 